\title{
Taide raivaa utopiaa arkeen
}

\author{
Hanna Johansson
}

Riikka Haapalainen, Utopioiden arkipäivää Osallistumisen ja muutoksen paikkoja nykytaiteessa 1980-2011. Helsingin yliopisto, 2018, $313 \mathrm{~s}$.

Riikka Haapalaisen väitöskirja tarkastelee osallistavaa nykytaidetta ja sen aiheuttamia muutoksia kuvataiteen teosmuodolle. Näistä keskeisin on taideteoksen esineellisyyden korvaantuminen erilaisia toimijoita sisältäväksi tapahtumaksi. Taiteen tapahtumallisuus ja teoksen käsitteen hämärtyminen on yksi keskeisimpiä 1900-luvun jälkipuolen taiteessa tapahtuneita muutoksia. Teosmuodon hajoaminen tai haurastuminen on myös monen nykytaiteen historian alaan lukeutuvan tutkimuksen aihe. Tutkimukset joutuvat kysymään yhä uudelleen; miten käsitteellistää, ymmärtää tai analysoida taidetta, jota ei voi paikantaa kiinteisiin teosobjekteihin eikä sisäisesti koherentteihin tapahtumiin vaan, jotka ovat "monimutkaisia, hajanaisia ja sotkuisia" tapahtumia (s.32), rihmastollisia kohtaamisia, materiaalin liikettä, pettäviä sopimuksia, tai jotka muistuttavat olemassa olevia yhteiskunnallisia instituutioita kuten kouluja, yliopistoja, ravintoloita tai kahviloita, olematta kuitenkin niitä. Usein ainoa jälkikäteinen pääsy näihin teoksiin on kasa erilaisia dokumentteja ja tallenteita; valokuvia, kassakuitteja, muistelmia ja haastatteluja, joista tutkijan on koottava paitsi teos mahdollisimman monine suhteineen ja erilaisine "osakkuuksineen" (kt.s.36), myös luotava sille mielekäs käsitteellinen konteksti.

Tällaisesta taiteesta kirjoittaminen edellyttää tutkijalta monenlaista notkeutta; notkeutta yhdistellä keskusteluja yli tieteenalojen, notkeutta tunnistaa tapahtumallisen teoksen "aineettomia" merkityksiä, kykyä suhteuttaa näitä taidehistorian ja nykytaiteen keskus-

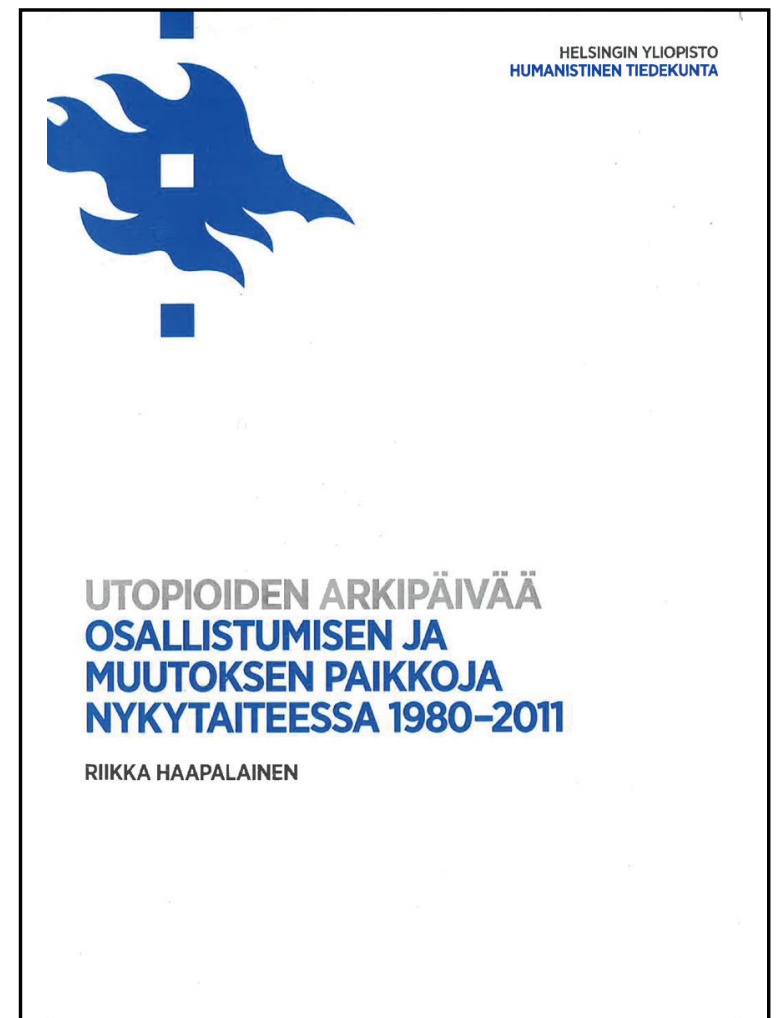

teluja vireästi liikkuviin tutkimuskysymyksiin ja säilyttää tässä tasapainoilussa eettinen taju teoksen ja tutkimuksen rajoista.

Haapalaisen Utopioiden arkipäivää ei yritä välttää osallistavan taiteen tutkimukseen liittyviä vaikeuksia 
vaan päinvastoin se lähtee kysymään, miten osallistava taide on, miten ja millaisia merkityksiä tapahtumalliset teokset tuottavat ja toisaalta, miten osallistavaa taidetta tulisi lähestyä, minkälaisin tutkimuksellisin konstellaatioin osallistavasta taiteesta tulisi ottaa selvää.

Haapalainen on ratkaissut moneen suuntaan avautuvan ja varsin heretogeenisen tutkimusaineiston käsittelemisen jäsentämällä tutkittavat teokset viiden tutun paikan tai paikkametaforan ympärille (katu, kahvila, kauppa, koulu, katedraali). Tutkimus tarkentuu näissä paikoissa tapahtuneiden kuuden teoksen analyysiin. Kaikki analysoitavat teokset ovat oman aikansa klassikoita. Kaksi niistä on toteutunut Helsingissä: Minna Heikinahon IImainen aamiainen (1992) tapahtui kahvilassa. Tanskalaisen taiteilijaryhmä Superflexin (tutkimuksen kauppa) Free Shop. Anything the customer wants to purchase is free (2003 alkaen) toteutui Helsingissä 2011 osana IHME-festivaalia. Näiden lisäksi väitöstutkimuksessa lähiluetaan kahta kadulle sijoittuvaa teosta: Sophie Callen Suite vénitiennessä (1980) taiteilija seurasi salaa Henri B:ski kutsumaansa mieshenkilöä Venetsiassa kahden viikon ajan. John Baldessarin Your name in Lights (2011 ja 2014) valospektaakkelia taas tarjosi osallistujilleen mahdollisuuden nähdä oman nimensä joidenkin sekuntien ajan neonvaloissa julkisessa kaupunkitilassa. Tutkimuksen koulu oli Copenhagen Free University (2001-2007), joka toimi sen perustajien Heise ja Jakob Jakobsenin kotona. Vapaan yliopiston toiminta perustui spontaanille ja itseohjautuvalle aktivismia muistuttavalle toiminnalle, jonka pontimena oli synnyttää vaihtoehtoja globaalille tietotaloudelle ja koulutuksen virtaviivaistumiselle. Katedraalina tutkimuksessa tarkasteltiin Francis Alÿsin Perussa toteutunutta When Faith Moves Mountain (2002) teosta, jossa joukko vapaaehtoisia siirsi hiekkavuorta lapioimalla. Analyysiluvuissa Haapalainen haastaa taiteen tutkimuksen metodeja ja laajentaa osallistavuuden käsitettä sekä edelleen näyttää osallistavan taiteen kytkentöjä yhteiskunnallisiin, uskonnollisin ja poliittisiin keskusteluihin.

Utopioiden arkipäivää näkee, että osallistavan taiteen keskeinen motiivi on tuottaa muutosta. Tämä tavoite liittää osallistavan taiteen luontevasti 1900-luvun alun avantgardeliikkeisiin, kuitenkin sillä erotuksella, että osallistavan taiteen ei tarvitse muuttaa yhteiskuntaa tai sen arvoja vaan riittää, että muutos tapahtuu yksilössä, satunnaisessa yhteisössä ja se voi olla pysyvää tai "hetkellisiä heittäytymisiä tai siirtymisiä uudenlaisiin suhteisiin"(s.44). Haapalaisen hyvin erilaisten analysoitavien teosten yhteisenä nimittäjänä on lähes aporeettinen sanapari: utopia ja arki. Utopia on paikka, jota ei ole, tai jota ei ole vielä, ja arki taas on se jokapäiväisyys, johon ei kiinnitetä erityistä huomiota. "Arki on sitä mikä jää yli, kun kaikki erityinen, erikoistunut ja strukturoitu on analysoitu pois", kuten Haapalainen kirjoittaa Henri Lefebvreä lainaten. (s.37). Osallistavan taiteen muutokseen tähtäävä utopia tulee ymmärtää "eräänlaisena heikon tai huokoisen utopian ilmauksena." (s.6). Huokoinen muutos on ennalta määrittelemätön ja se voi tapahtua yllättäen arjen toistuvien rutiinien keskellä.

Tutkimuksessa tunnistetaan ja korostetaan osallistavan taiteen suhdetta yhteiskunnallisuuteen, ja sen kiinnittymistä muihin kuin taiteen kentän sisäisiin keskusteluihin, toimintastrategioihin ja arvottamisen kriteereihin. Tämän vuoksi on loogista, että Haapalaisen tutkimuksen teoreettinen tausta on moniaineksinen: käsitteistöä haetaan taiteen- ja kulttuurintutkimuksesta, filosofiasta sekä yhteiskuntatieteistä.

Vaikka Utopioiden arkipäivää nojaa ja jatkaa osallistavasta taiteesta käytyä keskustelua muun muassa Irit Rogoffin ja Claire Bishopin jäljillä, tutkimus ei pyri normatiivisesti määrittelemään mitä osallistava taide on tai vielä vähemmän, mitä sen pitäisi olla. Tällä asenteella Haapalainen onnistuu laventamaan osallistavan taiteen alaa ja tarkastelee osallistavana taiteena myös teosta - Sophie Callen Suite Vénitienne (1980) - jota aiempi tutkimus ei ole mieltänyt osallistavaksi taiteeksi. Näkökulman ja määrittelyn laventaminen on tuottoisaa. Analyysi tarjoaa oivaltavia ja hyvin perusteltuja näkökulmia tähän Callen kutkuttavaan ja aikoinaan myös hämmennystä aiheuttaneeseen teokseen, ja sa- 
malla näyttää nykytaiteen paradigmaattisen luonteen. Jokaisen teoksen kohdalla on erikseen kysyttävä, miten teos on ja tapahtuu, mihin kaikkialle se ulottuu, mitä se saa aikaan ja mihin se on suhteessa?

Tutkimuksen läpäisevänä käsitteellisenä rihmana on siis kuudessa analysoitavassa teoksessa hahmottuvien erilaisten suhteiden lisäksi unelmien tai utopioiden erimuotoinen toteutuminen sekä se, miten utopian toimeenpaneminen tapahtuu tutkittavien esimerkkien kohdalla. Unelma voi olla yhteistä uskoa muutokseen, kahvittelua, toisten kuuntelua, kodin avaamista vieraalle, yhdessä oppimista, hetkellinen katkos talouden vääjäämättömältä tuntuvaan vaihdon logiikkaan, tai oman salapoliisivietin seuraamista. Olennaista osallistavassa taiteessa on unelman toimeenpaneminen, sen saattaminen passiivisesta suunnitelmasta yhteisölliseksi aktiviteetiksi.

Haapalaisen tutkimuksen valossa näyttää siltä, että utopiat toteutuvat osallistavan taiteen kohdalla nimenomaan jokapäiväisissä rutiineissa, joiden siirtäminen sijoiltaan tai muuttaminen on tullut mahdolliseksi juuri taiteen keinoin. Osallistavan taiteen utopiat eivät ole jossain muualla paremmassa tulevaisuudessa vaan utopioita on mahdollista toteuttaa muun muassa leikin ja aktivismin keinoin, juuri nyt tässä, arjen tilanteessa.

Haapalaisen tutkimuksen eri luvut paneutuvat aina uuteen teoreettiseen maastoon, jota perataan melkoisen kirjallisen aineksen tuella. Parhaimmillaan teosten analyysit nousevat laajoiksi yhteiskunta-analyyseiksi ja oman aikamme kritiikeiksi, kuten Minna Heikinahon IImaisen aamiaisen kohdalla. Ja hyvä niin, sillä tällöin tutkimus vastaa teosten haasteeseen. Se muuttaa kokemustamme ja ymmärrystämme todellisuudesta.

Paikoitellen nämä jokaisessa luvussa tehtävät sukellukset yhteiskunnallisfilosofiseen keskusteluavaruuteen raskauttavat lukemista ja ovat vaarassa tukahduttaa varsinaisen uuden tiedon. Ravistelemalla sopivasti oppineisuuden osoittavaa kirjallista aineistoa sivuun, nousee esiin hienoja analyyseja ja narratiiveja, jotka avaavat sekä teosten taustoja että temaattisia polkuja niiden ympärille. Tutkimus antaa tulokseksi ajatuksen utopiasta eräänlaisena kotiarkistona, ja koti onkin tutkimuksen kuudes paikka: "Näiden konkreettisesti realisoituvien utopioiden sijaan koti tässä tutkimuksessa heijastelee ajatusta arkistosta, joka on jokaisella mukana kulkeva ja jatkuvasti täydentyvä tiedollinen ja kokemuksellinen varanto, jonka kautta asiat saavat merkityksensä. (s. 219)"

Haapalainen rakentaa läpi koko tutkimuksensa osallistavan taiteen suhdetta moderniin ja modernismiin, modernista elämäntapaan ja yhteiskunnalliseen ajatteluun ja aikakauteen. Historiallisen avantgarden merkitys osallistavalle taiteelle, ja sen intentioille sekä siten Haapalaisen tutkimukselle on perusteltu. Paikka paikoin modernista tulee kuitenkin asetelmallinen käsite, jota kuljetetaan mukana perustelematta sen käyttö- tapoja. Itse hukkasinkin langan, joka yhdistää modernin teoriat ja modernismin läpityöstetyt opinkappaleet nykytaiteen paradigmoihin liittyvään taiteeseen. Jos ei sitten ole kyse modernin uudelleenluennasta, joka sinällään on kiinnostava mahdollisuus.

Haapalaisen väitöstutkimus on kirjoitettu ja julkaistu suomeksi, ja tässä mielessä se lunastaa oman tärkeän paikkansa suomeksi kirjoitetun nykytaiteen ja sen historian tutkimuksen kentällä. Kielivalinta on sikäli kiinnostava, että tekijä ei määrittele kuitenkaan oman työnsä paikkaa suomalaisessa taiteentutkimuksessa. Tämä voidaan nähdä perusteltuna aikana, jolloin kansallinen tiede ja suomen kieli kuulostavat pejoratiivisilta. Samaan aikaan meidän tulisi kuitenkin tunnistaa oman lokaatiomme kielellinen, maantieteellinen ja kulttuurinen erityisyys, kansallisuudesta viis

Haapalaisen välinpitämättömyys Suomessa ja suomeksi tehtyä alan tutkimusta kohtaan on hämmentävä siksikin, että nykytaiteen historian akateemisen tason tutkimuksen tila Suomessa on heikko ja erityisesti suomenkielistä tutkimusta arvostetaan ja tehdään niukasti puhumattakaan suomalaisen taiteen tutkimuksesta. Toivottavaa olisikin, että tutkijat ainakin tuntisivat ja tunnistaisivat toistensa tekemiset ja näkisivät vaivaa niiden vuoksi. Jos suomalaiset kollegat eivät välitä toistensa edes suomeksi (saatikka muilla kielillä) tehdystä tutkimuksesta, voidaan hyvällä syyllä kysyä: kenelle Suomessa tehdään taidehistorian tutkimustra- 
ditioon sijoittuvaa nykytaiteen tutkimusta tai taidehistoriaa ylipäänsä?

Utopioiden arkipäivää. Osallistumisen ja muutoksen paikkoja nykytaiteessa 1980-2011 tutkimus tarkastelee nykytaidetta arjen mullistajana, yhteiskunnallisena ja sosiaalisena muutosvoimana. Haapalaisen mukaan osallistavan taiteen käytännöt murtavat hegemonista ja yksiäänistä (tai yksisuuntaista) valtaa sekä tuovat esiin tapoja toimia yhteiskunnassa toisin taiteen nimissä. Taide näyttää tarjoavan sekä mikrotason että makrotason vaihtoehtoja; muutoksia yksittäisten inmisen yksityisistä arjen tapahtumissa aina instituutioita, kuten yliopiston toimintaa koskeviin kannanottoihin. Tässä mielessä Utopioiden arkipäivää -teos on poliittinen.

FT Hanna Johansson on Helsingin yliopiston taidehistorian dosentti. Hän työskentelee Taideyliopiston Kuvataideakatemiassa Nykytaiteen tutkimuksen professorina. 